\title{
Fractionation distribution and ecological risk assessment of some trace metals in artificial estuary: Vridi channel (Côte d'Ivoire)
}

\author{
Yao Marcel Konan, Trokourey Albert
}

Felix Houphouet-Boigny University, UFR SSMT, Faculty of Physics Chemistry, 22 BP 582 Abidjan 22, Abidjan, Côte d'Ivoire

Correspondence Author: Yao Marcel Konan, Felix Houphouet-Boigny University, UFR SSMT, Faculty of Physics Chemistry, 22 BP 582 Abidjan 22, Abidjan, Côte d'Ivoire,

E-mail:yaomarcelkonan@gmail.com , Phone: +225 07130942

Received date: 23 February 2018, Accepted date: June 2018, Online date: 10June 2018

Copyright: (C) 2018 Yao Marcel Konan, Trokourey Albert. This is an open-access article distributed under the terms of the Creative Commons Attribution License, which permits unrestricted use, distribution, and reproduction in any medium, provided the original author and source are credited.

\begin{abstract}
BACKGROUND: The modified of Community Bureau of Reference (modified BCR) sequential extraction procedure has been one of common methods used for the trace metals speciation in sediments and allowed to the assessment of the ecological risk state of aquatic ecosystem based on ecological risk indexes. OBJECTIVE: The modified BCR sequential extraction procedure was used to the fractionation distribution of $\mathrm{Cd}, \mathrm{Co}, \mathrm{Cu}, \mathrm{Ni}, \mathrm{Pb}$ and $\mathrm{Zn}$ in sediment samples of Vridi channel, and three ecological indexes based on this method were used to assessment contamination and ecological risk state of these sediments. RESULTS: show that $\mathrm{Cd}$, $\mathrm{Co}$ and $\mathrm{Cu}$ are mostly under their exchangeable form and bound to carbonates $(92.07 \%$, $31.20 \%$ and $32.02 \%$ respectively for $\mathrm{Cd}$, Co and $\mathrm{Cu}$ ), Pb mostly bond to Fe-Mn oxihydroxides (32.52\%) and to organic matters and sulphides (32.21\%), Zn mostly under its residual fraction (18.33\%) and bond to Fe-Mn oxihydroxides (20.41\%) and Ni mostly under its residual fraction (42.06\%). These sediments present high contamination and ecological risk states of mainly in Cd, particularly its exchangeable form and that bound to carbonates. CONCLUSION: This present state of Vridi channel is essentially due to the strong anthropogenic pressures doing on this ecosystem. This study deserves to be widened in other hazardous pollutants to establish unequivocal the sanitary state of this estuary.
\end{abstract}

Key words: Ecological risk, Marine pollution, Metal speciation, Trace metals, Vridi Channel, Côte d'Ivoire.

\section{INTRODUCTION}

Given its economic weight in the West Africa Monetary Zone (40\%), Côte d'Ivoire is dealing with a massive and uncontrolled immigration. This situation causes uncontrolled urbanization with an important development and intensification of anthropogenic activities. These circumstances impact seriously its full ecological system, in particular its surface waters as shown by several studies [1-3]. The metallic pollution is one of the consequences resulting from these facts.

The metallic pollution of aquatic systems is major concern, due to their toxicity, persistence, non biodegradability and diversity of their sources [4-7]. Contrary to overlying waters, sediments can accumulate higher levels of hazardous trace metals discharged into aquatic systems through adsorption and coagulation, or flocculation, incorporation, and precipitation [8-9]. So, sediments are rich source of trace metals as well point of source of the metallic pollution, which may affect the entire food chain by their release into overlying waters through biological and chemical process [10-11]. Therefore, the ecological risk assessment dues to trace metals in sediments are so important. Although, the total concentration of trace metals in sediments gives valuable information on overall pollution level [12-13], they don't provide enough information to understand their various forms, mobility, bioavailability or potential risk to environment [14-15]. In opposite, a fractionation distribution (metal speciation analysis) can give more information about it and be a good indicator of the aquatic ecosystem quality for the metallic pollution. In effect, the fraction distribution reflects the specific bond state of elements in soils and sediments and induces a critical impact upon their mobility and bioavailability in environment [16-17]. Several procedures of trace metals speciation in sediments exist, including the modified Community Bureau of Reference (modified BCR) sequential extraction procedure. This procedure has been one of common methods used for the trace metals speciation in sediments. It derives from earlier BCR sequential extraction procedure [18] by works of Rauret et al. [19]. Its accuracy and reproducibility has been shown by several studies $[12,20-21]$. On the basis of trace metals fractionation, many methodologies were developed to assess their combined ecological risks in sediments, including the Contamination Factor (CF) [11], the Risk Assessment Code (RAC) [22] and the Modified Potential Ecological Risk Index (MPERI) [15].

Located at the bottom of Abidjan district, Vridi channel is the single pass between the Ébrié system and the Ocean Atlantic. It is located at in the south of Côte d'Ivoire, exactly at $5^{\circ} 15^{\prime} 23 \mathrm{~N}$ and $4^{\circ} 0^{\prime} 50^{\prime \prime} \mathrm{W}$. This artificial estuary is achieved by the breakthrough of the spit near Jacqueville dam when performing the autonomous harbour of Abidjan in 1933. It is $2.7 \mathrm{Km}$ long and $370 \mathrm{~m}$ wide, with depths ranging from 12 to $15 \mathrm{~m}$ and pits ranging from 10 to $25 \mathrm{~m}$ [23]. The streams of water are highly important (around $1.5 \mathrm{~m} / \mathrm{s}$ ) [24]. Due to the Atlantic Ocean, its watershed is invaluable, but that in continental environment relates to that of the Ébrié system $\left(93,600 \mathrm{Km}^{2}\right)$. This estuary is of exchange of all anthropogenic rejections (waste waters, solid detritus, etc.) between the system Ébrié and the Atlantic Ocean, particularly those of the harbour industrial zone and the industrial zone of Yopougon. It receives again all pollutants transported by Agnéby and Mé rivers, especially of the Comoé river, the most important river of this country (with $82,408 \mathrm{Km}^{2}$ of watershed) which drains all the east of this country [25] (Fig. 1). So, its biodiversity and sustainable development are seriously threatened. For illustration, Yao et al. [13] have shown the progressive degradation of this estuary with its high ecological risk, due to the metallic pollution. For this reason, it is important to purchase this kind of study in this bay for more information. It is in this context this study was conducted with following objectives: (i) analyze the fractionation of $\mathrm{Cd}, \mathrm{Co}, \mathrm{Cu}, \mathrm{Ni}, \mathrm{Pb}$ and $\mathrm{Zn}$ in the top layer of sediments of 
Vridi channel by using modified BCR sequential extraction procedure and (ii) to evaluate enrichment of trace metals in these sediments, and its ecological risks due to these trace metals.

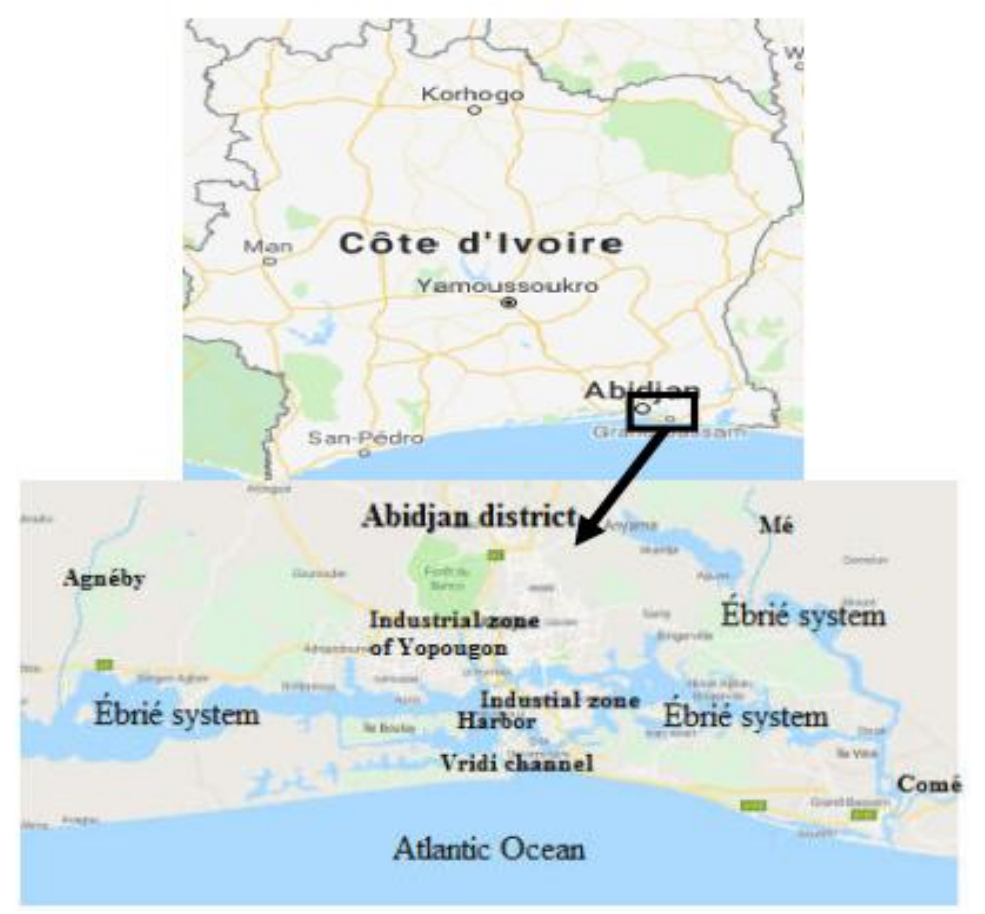

Fig. 1: Study area and its environments

\section{MATERIAL AND METHODS}

\subsection{Samples collection and preparation:}

For more details about values of concentrations of trace metals studies in this estuary, monthly sampling was done at three stations (Fig.2) for one year (April 2014-March 2015). Samples were collected upper $5 \mathrm{~cm}$ of the sediment-bed surface using a Wan-Veen type grab according to AFNOR certification X31-100 [26], put in polyethylene bottles (previously washed in $\mathrm{HNO}_{3}{ }^{-}$at $10 \%$, rinsed thoroughly with distilled water and dried in the steam) and stored at $4{ }^{\circ} \mathrm{C}$ in ice. In laboratory, samples were firstly cleaned coarse elements according to the AFNOR certification NF EN ISO 16720 [27], then were screened through a sieve diameter equal to $2 \mathrm{~mm}$ in accordance with AFNOR certification NF X 31-107 [28]. Sub-samples were put in dry and clean polyethylene bottled and stored in dark and cool place $\left(20^{\circ} \mathrm{C}\right)$ for further analysis.

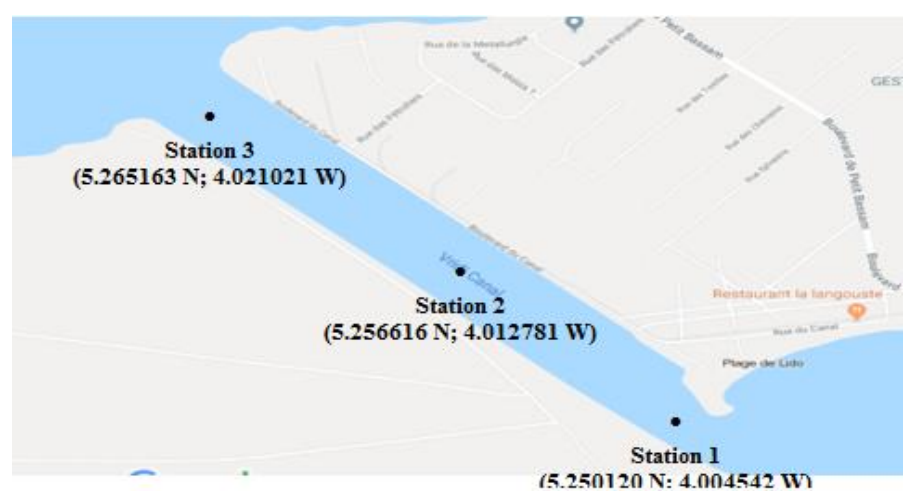

Fig. 2: Sampling sites

\subsection{Determination of the total concentration:}

The determination of the total concentration of trace metals studies was doing by digestion with the acid mixture (aqua regia $\left(\mathrm{HNO}_{3}: \mathrm{HCl}_{1} ; 1: 3\right.$ (v/v) and $\mathrm{HF}$ )) according to AFNOR certification NF T90-112 [29]. Vessels containing $1 \mathrm{~g}$ of sediments and $20 \mathrm{ml}$ of the acid mixture $\left(15 \mathrm{ml} \mathrm{HNO}_{3}^{-}+5 \mathrm{ml} \mathrm{HCl}+2 \mathrm{ml} \mathrm{HF}\right)$ were heated in sand-bath heater. Firstly, the digest was filtered through Whatman filter paper into $50 \mathrm{ml}$ flask, let cooled at the room temperature and treated by $20 \mathrm{ml}$ $\mathrm{H}_{3} \mathrm{BO}_{3}(135 \mathrm{~g} / \mathrm{L})$ and finally completed at $50 \mathrm{ml}$ by distilled water. The total concentration of trace metals was measured using an air-acetylene flame using atomic absorption spectrophotometer VARIAN AA 1275.These analyzes were performed in triplicate.

\subsection{Modified BCR sequential extraction procedure:}

Modified BCR extraction sequential procedure provides four fractions of trace metals in sediments: the acid extractable fraction (water soluble, exchangeable and bound to carbonates) (Fraction 1 (F1)), the reducible fraction (bond to Fe-Mn oxihydroxides) (Fraction 2 (F2)), the oxidizable fraction (bond to sulphides and organic matter) (Fraction 3 (F3)) and the residual (inert) fraction (Fraction 4 (F4)). The obtaining of these fractions is described by Nemati et al. [30] as follow:

- For the obtaining F1 (first step), $40 \mathrm{ml}$ of $0.11 \mathrm{M} \mathrm{CH}_{3} \mathrm{CO}_{2} \mathrm{H}$ was added to $1 \mathrm{~g}$ of the sample in a centrifuge tube and shaken for $16 \mathrm{~h}$ at the room temperature. The extract was then separated from the solid residue by centrifugation for $20 \mathrm{mn}$ at $3000 \mathrm{rpm}$, and the resultant supernatant liquid was transferred into a polyethylene flask. The residue was washed by adding $20 \mathrm{ml}$ of deionised water, shaken for $15 \mathrm{mn}$ on the end-over-end shaker, and centrifuged for $20 \mathrm{mn}$ at $3000 \mathrm{rpm}$. Subsequently, the supernatant was decanted and transferred into a flask polyethylene contained already the first supernatant; 
- The residue from first step is using for obtaining F2 (second step). So, $40 \mathrm{ml}$ of a freshly prepared $0.1 \mathrm{M} \mathrm{NH}_{2} \mathrm{OH}$ was added to the residue from step 1 in the centrifuge tube and re-suspended by mechanical shaking for $16 \mathrm{~h}$ at the room temperature. The separation of the extract, the collection of the supernatant and the rising of residues were doing as describe in step 1;

- As concerned for the obtaining F3 (step 3), the residue in step 2 was treated twice with $10 \mathrm{ml}$ of $8.8 \mathrm{M} \mathrm{H}_{2} \mathrm{O}_{2}$. First, $10 \mathrm{ml}$ of $\mathrm{H}_{2} \mathrm{O}_{2}$ was added to the residue from step 2 in centrifuge tube. Digestion was allowed to proceed at the room temperature for $1 \mathrm{~h}$ with occasional manual shaking, followed by the digestion at $85 \pm 2{ }^{\circ} \mathrm{C}$ for another $1 \mathrm{~h}$ in water bath. During the digestion, the centrifuge tube was loosely covered to prevent substantial loose of $\mathrm{H}_{2} \mathrm{O}_{2}$. Following that, the centrifuge tube was uncovered, and the heating was continued as before until the volume reduced to about 2-3 ml. An additional $10 \mathrm{ml}$ of $\mathrm{H}_{2} \mathrm{O}_{2}$ was added to the tube, covered and digest with cover at $85 \pm 2{ }^{\circ} \mathrm{C}$ for another $1 \mathrm{~h}$. the heating was continued as before until the volume reduce to $2-3 \mathrm{ml}$. Finally, $50 \mathrm{ml}$ of $1 \mathrm{M}$ $\mathrm{NH}_{4} \mathrm{OAc}$ was added to the cold mixture and shaken for $16 \mathrm{~h}$ at the room temperature. The separation of the extract, the collection of the supernatant and the rising of residues were the same as describe in step 1 ;

- F4 (step 4) was obtained by the digestion of the residue of step 3 as doing for the determination of the total concentration of trace metals.

These analyzes were performed in triplicate and the concentration of trace metals in different fractions were measured using an air-acetylene flame using atomic absorption spectrophotometer VARIAN AA 1275.

To explain possible interferences of reagents with samples, it is calculated the recovery rate $(\mathrm{R})$. $\mathrm{R}$ is given by follow formula: $\mathrm{R}(\%)=\frac{\mathrm{F} 1+\mathrm{F} 2+\mathrm{F} 3+\mathrm{F} 4}{\mathrm{FT}} \times 100$

(with FT is the total concentration of the trace metal).

The reference material BCR 667, corresponding to marine estuaries, was used to verify the reproducibility and precision of this method.

\subsection{Ecological risks indexes used:}

To assess correctly the ecological state of Vridi channel, it was used three ecological risk indexes: The Contamination Factor (CF), the Risk Assessment Code (RAC) and the Modified Potential Risk Index (MPERI).

\subsubsection{Contamination Factor $(C F)$ :}

$\mathrm{CF}$ is important for the determination of the degree of ecological risks due to trace metals in relation with their retention time. A high CF of the trace metal implies its low retention time and a high-risk degree to the aquatic environment [31-32]. Two indices of CF are commonly used: Individual Factor Contamination $\left(\mathrm{IFC}_{\mathrm{i}}\right)$ and Global Factor Contamination (GFC), defined respectively by:

$\mathrm{IFC}_{\mathrm{i}}=\frac{\mathrm{F} 1+\mathrm{F} 2+\mathrm{F} 3}{\mathrm{~F} 4}$

$\mathrm{GFC}=\sum_{\mathrm{i}=1}^{\mathrm{n}} \mathrm{IFC}_{\mathrm{i}}$

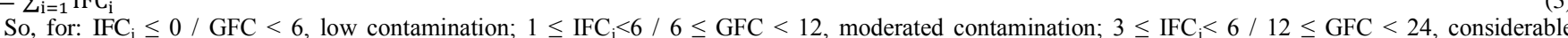
contamination; $\mathrm{IFC}_{\mathrm{i}}>6 / \mathrm{GCF}>24$, very high contamination [31-33].

\subsubsection{Risk Assessment Code (RAC):}

Defined by Perin et al. [22], RAC establishes an approach of ecological risks based on trace metals bioavailability in sediments (value of F1). According to value of F1, it is defined a toxicity index $(\delta)$ and the ecological risk state. So, for: $\mathrm{F} 1<1 \%, \delta=1.00$, no ecological risk; $1 \% \leq \mathrm{F} 1 \leq 10 \%, \delta=1.00$, low ecological risk; $11 \% \leq \mathrm{F} 1 \leq 30 \%, \delta=1.20$, average ecological risk; $31 \% \leq \mathrm{F} 1 \leq 50 \%, \delta=1.40$, high ecological risk; F1 $\geq 50 \%, \delta=1.60$, very high ecological risk.

\subsubsection{Modified Potential Ecological Risk Index (MPERI):}

Developed by Zhuang et al. [15], MPERI is the modification of Potential Ecological Risk Index (PERI) defined by Hankason [34]. This modification is based on the real total concentration of the trace metal $(\mathrm{FT})$ by the statement of "the modified total concentration of trace metal $\left(\widetilde{F_{T}}\right)$ " $(5)$ using the new toxicity index $(\Omega)$ (depend of the value of F1 and toxicity index ( $\delta$ ) obtained according to RAC [22]) (4). So, Individual Potential Ecological Risk (ER)(6) and MPERI (7) are obtained as follow:

$\Omega=\mathrm{F} 1 \times \partial+(1-\mathrm{F} 1)$

$\widetilde{\mathrm{FT}}=\mathrm{FT} \times \Omega$

$\mathrm{E}_{\mathrm{R}}^{\mathrm{i}}=\mathrm{T}_{\mathrm{R}}^{\mathrm{i}} \times \widetilde{\mathrm{F}_{\mathrm{T}}}$

MPERI $=\sum_{\mathrm{i}=1}^{\mathrm{n}} \mathrm{E}_{\mathrm{R}}^{\mathrm{i}}$

with: $\mathrm{T}_{\mathrm{R}}{ }^{\mathrm{i}}$, the toxic-response factor for a given trace metals $(\mathrm{Cu}=\mathrm{Pb}=\mathrm{Ni}=5, \mathrm{Zn}=1, \mathrm{Cd}=30) ; F_{R}^{i}$, the pre-industrial total concentration of trace metal in sediments, taken from those provided by Wedepohl [35] for the upper continental crust.

So, for: $\mathrm{E}_{\mathrm{R}}^{\mathrm{i}}<40$ / MPERI $<150$, low contamination; $40 \leq \mathrm{E}_{\mathrm{R}}^{\mathrm{i}}<80 / 150 \leq \mathrm{MRI}<300$, moderated contamination; $80 \leq \mathrm{E}_{\mathrm{R}}^{\mathrm{i}}<160 / 300 \leq \mathrm{MRI}<600$, considerable contamination; $160 \leq \mathrm{E}_{\mathrm{R}}^{\mathrm{i}}<320$, high contamination; $\mathrm{E}_{\mathrm{R}}^{\mathrm{i}} \geq 320 / \mathrm{MRI} \geq 600$, very high contamination.

\subsection{Technical statistics used:}

All data were expressed as mean \pm standard deviation $(\mathrm{m} \pm \mathrm{SD} ; \mathrm{n}=3)$ and tested for normality and homogeneity of variance to check whether, or not they meet statistical demand. The correlation matrix of Bravais-Pearson was performed to verify relationships between trace metals studies. All calculations were doing by the Statistica software package version 10.0.

\section{RESULTS AND DISCUSSION}

\subsection{Fractionation distribution of trace metals studies:}

As shown table 1 and fig.3, $\mathrm{Cd}, \mathrm{Ni}$ and $\mathrm{Pb}$ present very high accuracy Values. These high recovery values can be explained by lower efficiency of digestion of the $\mathrm{HF}$ acid mixture with high Ca content, which trapped calcium fluoroaluminate or calcium precipitates and was affected by interferences [36-38]. Also, it is hypothesized that $\mathrm{Ni}$ and $\mathrm{Pb}$ in these samples are partly associated with HF-refractory minerals such as Fe-Mn oxihydroxides, which act as a trap for these trace metals. In effect, these oxides are excellent scavengers for trace metals and can be mobilized under acidic conditions [39-40].

$\mathrm{Cd}$ is mainly present in this estuary under exchangeable form and bond to carbonates $(92.07 \%)$. It is the same case of Co and $\mathrm{Cu}$ but in a lesser proportion (31.2\% and $32.02 \%$ respectively for $\mathrm{Co}$ and $\mathrm{Cu}$ ). As their exchangeable form and that bond to carbonates, $\mathrm{Co}$ and $\mathrm{Cu}$ present practically the same value in their fraction bound to organic matters and sulphides (13.15\% for Co and 13.80 for $\mathrm{Cu}$ ), but also in that bound Fe-Mn oxihydroxides (12.96\% for Co and $13.53 \%$ for $\mathrm{Cu})$; in opposite of their residual fraction (19.66 for Co and 13.59 for $\mathrm{Cu}$ ). As for $\mathrm{Ni}$, it is mainly under its residual fraction $(42.06 \%)$ and presents practically the same proportion in its fraction bound to Fe-Mn oxihydroxides $(20.72 \%)$ and that bound to organic matters and sulphides $(19.41 \%)$. Its exchangeable form and that bound to carbonates are relatively weak (13.24\%). The fraction of $\mathrm{Pb}$ bound to $\mathrm{Fe}-\mathrm{Mn}$ oxihydroxides and that bound to organic matters and sulphides, with practically the same proportion (respectively of $32.52 \%$ and $32.21 \%$ ), are its most important fractions. Its residual fraction (26.60 \%) is relatively also more important than for its exchangeable form and that bound to carbonates $(12.13 \%)$. Zn is majority under its residual fraction (18.33\%) and bond to Fe-Mn oxihydroxides (20.41\%). Its fractions bond to organic matters and sulphides (11.84\%) and its exchangeable form and that bond to carbonates $(9.52 \%)$ are slightly important.

The high salinity of this estuary would favour the relative high presence of $\mathrm{Cd}, \mathrm{Cu}$ and $\mathrm{Co}$ in their exchangeable form and that bound to carbonate. For $\mathrm{Cd}$, the salinity would cause this fact by the formation of $\mathrm{CdCl}_{2}$ complex. The stability and solubility of this complex is high while the affinity for sorption to the soluble phase is low [41]. Again, the salinity would affect the binding of $\mathrm{Cd}$, $\mathrm{Co}$ and $\mathrm{Cu}$ to humic substances [42], which they present high affinities [43]. An 
increase in the concentration of major cations $\left(\mathrm{Na}^{+}, \mathrm{K}^{+}, \mathrm{Ca}^{2+}, \mathrm{Mg}^{2+}\right)$, due to an increase of the salinity, would for the formation of this fraction by competing on various adsorption sites [17, 41]. The reducing character of sediments of this estuary [13] and microbial activities would contribute to it too, by reduction of their Fe-Mn oxihydroxides and sulphides compounds [14, 44]. These phenomena have a particular importance for Cd with regard to Co and Cu. Salinity and redox process are hardly influenced $\mathrm{Pb}$, because it seems to be bound more to high molecular weight organic matter compounds than humic substances in organic matters $[39,45-46]$. That is the same case for the binding of $\mathrm{Pb}$ and $\mathrm{Zn}$ to Fe-Mn oxihydroxides, which would be explained by the high affinity of these trace metals to these oxides [47]. These observations doing on the reducible fractions of $\mathrm{Pb}$ would seem to be the same in the case of $\mathrm{Ni}$ (essentially under inert fraction), but in a lesser degree.

All the reducible fraction of trace metals studies, superior to $50 \%$, illustrates that they in their majority outcomes of the rejections of anthropogenic activities, particularly those of autonomous harbor of Abidjan and its industrial zone, well as those of industrial zone of Yopougon [13]and those transported by the Comoé river[25]. The strong positive correlation between $\mathrm{Co}, \mathrm{Cu}$ and $\mathrm{Zn}$ (Tableau 3) shows that these trace metals are the same origin. Again, the correlation value between $\mathrm{Co}$ and $\mathrm{Cu}$ would confirm that they have a similar mobility in sediments of this channel.

Table 1: Means values $( \pm \mathrm{SD})(\mathrm{n}=3)$ of trace metals studies and their recovery rate $(\mathrm{R})$

\begin{tabular}{|c|c|c|c|c|c|c|}
\hline & $\begin{array}{l}\mathrm{Cd} \\
(\mathrm{mg} / \mathrm{Kg})\end{array}$ & $\begin{array}{l}\text { Co } \\
(\mathrm{mg} / \mathrm{Kg})\end{array}$ & $\begin{array}{l}\mathrm{Cu} \\
(\mathrm{mg} / \mathrm{Kg})\end{array}$ & $\begin{array}{l}\mathrm{Ni} \\
(\mathrm{mg} / \mathrm{Kg})\end{array}$ & $\begin{array}{l}\mathrm{Pb} \\
(\mathrm{mg} / \mathrm{Kg})\end{array}$ & $\begin{array}{l}\mathrm{Zn} \\
(\mathrm{mg} / \mathrm{Kg})\end{array}$ \\
\hline F1 & $3,95 \pm 1.48$ & $23,22 \pm 3.12$ & $3,16 \pm 0.16$ & $8,76 \pm 5.71$ & $19,47 \pm 19.93$ & $7,44 \pm 5.06$ \\
\hline $\mathrm{F} 2$ & $0,19 \pm 0.02$ & $16,97 \pm 4.10$ & $2,55 \pm 1.19$ & $18,89 \pm 4.65$ & $69,07 \pm 13.29$ & $33,81 \pm 11.05$ \\
\hline F3 & $0,06 \pm 0.02$ & $14,98 \pm 1.19$ & $2,25 \pm 0.60$ & $14,03 \pm 3.52$ & $46,16 \pm 13.06$ & $15,61 \pm 5.18$ \\
\hline $\mathrm{F} 4$ & $0,09 \pm 0.05$ & $19,45 \pm 2.62$ & $1,91 \pm 0.63$ & $24,5 \pm 10.55$ & $25,84 \pm 10.55$ & $21,31 \pm 10.55$ \\
\hline FT & $2,37 \pm 0.22$ & $79,47 \pm 9.42$ & $12,14 \pm 8.20$ & $33,75 \pm 12.71$ & $71,31 \pm 20.97$ & $94,95 \pm 42.77$ \\
\hline $\mathrm{R}(\%)$ & 181,01 & 93,90 & 81,30 & 196,10 & 225,13 & 82,33 \\
\hline
\end{tabular}

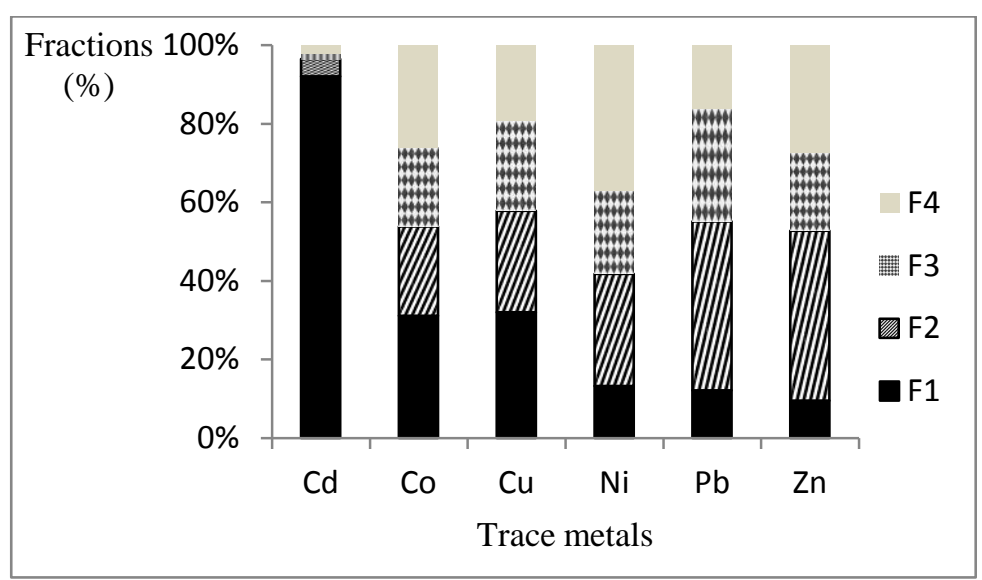

Fig. 3: Proportions of trace metals studies in different fractions

Table 2: Correlation matrix of Bravais-Pearson for trace metals studies

\begin{tabular}{|l|l|l|l|l|l|l|}
\hline & $\mathrm{Cd}$ & $\mathrm{Co}$ & $\mathrm{Cu}$ & $\mathrm{Ni}$ & $\mathrm{Pb}$ & \\
\hline $\mathrm{Cd}$ & 1,00 & & & & & \\
\hline $\mathrm{Co}$ & 0,42 & 1,00 & & & & \\
\hline $\mathrm{Cu}$ & 0,42 & 1,00 & 1,00 & & & \\
\hline $\mathrm{Ni}$ & $-0,17$ & 0,77 & 0,74 & 1,00 & & \\
\hline $\mathrm{Pb}$ & $-0,27$ & 0,51 & 0,57 & 0,57 & & \\
\hline $\mathrm{Zn}$ & 0,13 & 0,94 & 0,94 & 0,88 & 1,00 & \\
\hline
\end{tabular}

*marked significant correlations at $\mathrm{p}<.05$ in bold

The recovery rate of trace metals studies from the reference material BCR 667 are very closely to $100 \%$ with relative low variances (Table 3). So, the reproducibility and accuracy of the modified BCR sequential extraction procedure with this reference material have shown again in this study, as already mentioned by Neves et al. [48] and Ribeiro et al. [49].

Table 3:Comparison between certified and found values $(n=3)$ for extractable trace metals in marine estuary sediment reference material BCR667

\begin{tabular}{|l|l|l|l|l|l|l|}
\hline & Cd & Co & Cu & Ni & Pb & Zn \\
\hline $\begin{array}{l}\text { Certified values }^{\mathrm{a}} \\
(\mathrm{mg} / \mathrm{Kg})\end{array}$ & $0.67 \pm 0.11$ & $23.0 \pm 1.3$ & $60.0 \pm 9$ & $128.0 \pm 9$ & $31.9 \pm 1.1$ & $175 \pm 13$ \\
\hline $\begin{array}{l}\text { Metals extracted } \\
(\mathrm{mg} / \mathrm{Kg})\end{array}$ & $0.66 \pm 0.08$ & $22.5 \pm 2.60$ & $59.75 \pm 8.56$ & $127.9 \pm 10.06$ & $30.1 \pm 5.3$ & $170.2 \pm 6$ \\
\hline Recorvery (\%) & 98.50 & 97.83 & 99.58 & 99.92 & 94.36 & 97.14 \\
\hline Variance & 9.50 & 7.42 & 8.60 & 9.43 & 6.50 & 7.46 \\
\hline
\end{tabular}

\subsection{Environmental implications:}

The different values of $\mathrm{CF}$ for each trace metals studies show that these sediments are moderately contaminated by trace metals studied, except for $\mathrm{Cd}$ which pollutes very highly these sediments. Therefore, $\mathrm{Cd}$ has a relatively a short residence time in these sediments. Because of $\mathrm{Cd}$, these sediments present a high contamination in these trace metals in view to its GFC value. Ecological risks which result are low for $\mathrm{Cu}, \mathrm{Ni}$ and $\mathrm{Zn}$, considerable for $\mathrm{Pb}$ and very high for $\mathrm{Cd}$ according their $E_{R}^{i}$ value; and very high for all these trace metals referred to MPERI value obtained. As concern for ecological risk due to their exchangeable form and that bound to carbonates, it is average for $\mathrm{Ni}, \mathrm{Pb}$ and $\mathrm{Zn}$, high for $\mathrm{Co}$ and $\mathrm{Cu}$, and very high for $\mathrm{Cd}$ (Table 4).

These results obtained confirm those obtained by Yao et al.[13]in these sediments. This state of Vridi channel is essentially due to high anthropogenic pressures doing on this estuary. 
Citation: Yao Marcel Konan, Trokourey Albert, 2018. Fractionation distribution and ecological risk assessment of some trace metals in artificial estuary: Vridi channel (Côte d'Ivoire). Advances in Natural and Applied Sciences., 12(6): 1-6.

Table 4: Values of trace metals in ecological risks indexes used

\begin{tabular}{|l|l|l|l|l|l|l|l|}
\hline & & Cd & Co & Cu & Ni & Pb & Zn \\
\hline Contamination factor & IFC & 46.67 & 2.84 & 4.17 & 1.70 & 5.21 & 2.67 \\
\cline { 2 - 8 } & GFC & 63.25 & \multicolumn{5}{|l|}{} \\
\hline \multirow{3}{*}{ Risk index } & $E_{R}^{i}$ & 2349.10 & - & 9.61 & 24.97 & 102.64 \\
\cline { 2 - 9 } & MRI & 2488.14 & \multicolumn{5}{|l|}{1.83} \\
\hline
\end{tabular}

\section{Conclusion:}

This present study showed that all trace metals studies have a strong mobility, excepted for $\mathrm{Ni}$ for whom this fact is relatively little important. The salinity and the hydrosystem of this estuary would contribute strongly to this phenomenon. High anthropogenic pressures on this estuary would entail a relative high presence of these trace metals, especially for $\mathrm{Cd}$. The immediate consequence of such an established fact is high contamination and ecological risk states of this ecosystem. The reproducibility and the precision of modified BCR sequential extraction procedure is shown in this study again.

Further works:

1. Extension of this study in other hazardous compounds such as $\mathrm{As}, \mathrm{Cr}$ and $\mathrm{Hg}$, pesticides.

2. Study of the seasonal dynamic of the fractionation of trace metals in this estuary.

3. Using of Artificial Neurons Network (ANN) for modelling spatial and temporal of some pollutants in relations with some physical and chemical parameters in this estuary

\section{ACKNOWLEDGEMENTS}

The authors are thankful to Oceanologic Research Center of Abidjan for the provision of all the material used in this study.

\section{REFERENCES}

[1] Abe, J., B. Brown, E.A. Ajao, S. Donkor, 2016. Local to regional polycentric levels of governance of the Guinea current large marine ecosystem. Environmental Development, 17(1): 287-295.

[2] N'Zi., K.G., S.S. Yao, B.G. Goore, V. Ndouba, 2015. Update of itchthyofauna diversity and ecological status of a coastal River Nero (Côte d'Ivoire-West Africa). Saudi Journal Biological Sciences, 22: 265-273.

[3] Seu-Anoï., N.M., N.K. Kouadio, Y.J-M. Koné, A. Ouattara, G. Gourène, 2018. Spatial and Temporal Distribution of Cyanobacteria and Their Relationship With Environmental Parameters In The Aby System Lagoon (south-eastern Ivory Coast, West Africa). Australian Journal of Basic and Applied Sciences, 12(1): 37-44.

[4] Belamri, M., L. Bounemia, A. Azbouche, K. Boukeffoussa, C.L. Chaouch, 2017. Assessment of air pollution by heavy metals in the urban center of Algiers. Australian Journal of Basic \& Applied Sciences, 11(5): 35-44.

[5] Karpagavalli, K., K. Raju, 2017. Effect of heavy metal pollution on groundnut (Arachis hypogaea L.) cultivar - A Spectroscopic study. Advances in Natural and Applied Sciences, 11(4): 120-122.

[6] Lee, P-K., M-J. Kang, S. Yu, K-S. Ko, K. Ha, S-C. Shin, J.H. Park, 2017. Enrichment and geochemical mobility of heavy metals in bottom sediments of the Hoedong reservoir (Korea) and their source apportionment. Chemosphere, 184: 74-85.

[7] Okoro, H.K., J.O. Ige, O.A. Iyiola, J.C. Ngila, 2017. Fractionation profile, mobility patterns and correlations of heavy metals in estuary sediments from Olonkoro river, in Tede catchment of western region, Nigeria. Environmental Nanotechnology, Monitoring \& Management, 8: 53-62.

[8] Hargreaves, A.J., P. Vale, J. Whelan, L. Alibardi, C. Constantino, G. Dotro, E. Cartmell, P.Campo,2018. Impacts of coagulation-flocculation treatment on the size distribution and bioavailability of trace metals $(\mathrm{Cu}, \mathrm{Pb}, \mathrm{Ni}, \mathrm{Zn})$ in municipal wastewater. Water Research, 128: 120-128.

[9] Rajasulochana, P., V. Preeth, 2016. Comparison on efficiency of various techniques in treatment of waste and sewage water-A comprehensive review. Resource-Efficient Technologies, 2(4): 175-184.

[10] Ghani, S.A.A., 2015. Trace metal in seawater, sediments and some fish species from Marsa Matrouh Beaches in north-western Mediterranean coast, Egypt. The Egyptian Journal of Aquatic Research, 41(2): 145-154.

[11] Yichen, L., M. Fanping, D. Yongxing, T. Yuhan, 2016. Distribution, speciation, and risk assessment of heavy metals in surface sediments of Jiaozhou Bay, China. Human Ecological Risk Assessment: An International Journal, 22(5): 1253-1267.

[12] Abdallah, M.A.M., 2017. Chemical speciation and contamination assessment of $\mathrm{Pb}$ and $\mathrm{V}$ by sequential extraction in surface sediment off Nile Delta, Egypt.Arabian Journal of Chemistry,10(1): 68-75.

[13] Yao, M.K., Y. S. Brou, A. Trokourey, M.B. Soro, 2017. Metal pollution and ecological risk assessment in sediments of artificial estuary: case of Vridi channel, Côte d'Ivoire. Journal of Applied Sciences and Environmental Management, 21(4): 785-792.

[14] Wang, Y., W. Han, X. Wang, H. Chen, F. Zhu, X. Wang, C. Lei, 2018. Speciation of heavy metals and bacteria in cow dung after vermicomposting by the earthworm, Eisenia fetida. Bioresource Technology,245(A): 411-418.

[15] Zhang, W., Y. Liu, Q. Chen, Q. Wang, F. Zhou, 2016. A new index for assessing heavy metal contamination in sediments of the Beujing-Hangzhou Grand canal (Zaozhuang Segment): A case study. Ecological Indicator, 69: 252-260.

[16] Lou, C., X. Liu, Y. Nie, S.D. Emslie, 2015. Fractionation distribution and preliminary ecological risk assessment of As, Hg and Cd in ornithogenic sediments from the Ross Sea region, East Antarctica. Science of the Total Environment, 538: 644-653.

[17] Zhu, X., J. Yao, F. Wang, Z. Yuan, J. Liu, G. Jordan, T. S. Knudsen, J. Avdalović, 2018. Combined effects of antimony and sodium diethyldithiocarbamate on soil microbial activity and speciation change of heavy metals. Implications for contaminated lands hazardous material pollution in nonferrous metal mining areas. Journal of Hazardous Materials,349: 160-167.

[18] Ure., A.M., P. Quevauviller, H. Muntau, B. Griepink, 1993. Speciation of Heavy Metals in Soils and Sediments. An Account of the Improvement and Harmonization of Extraction Techniques Undertaken Under the Auspices of the BCR of the Commission of the European Communities. International Journal of Environmental Analytical Chemistry, 51: 1-4

[19] Rauret., G., J.F. Lopez-Sanchez, A. Sahuquillo, R. Rubio, C. Davidson, A.M. Ure, P. Quevauviller, 1999. Improvement of the BCR three step sequential extraction procedure prior to the certification of new sediment and soil reference material. Journal of Environmental Monitoring, 1: 57-61.

[20] Garcia-Ordiales, E., S. Covelli, J.M. Esbri, J. Loredo, P.L. Higueras, 2016. Sequential extraction procedure as tool to investigate PTHE geochemistry and potential geoavailability of DAM sediments (Almadénminimg district, Spain). Catena, 147: 394-403.

[21] Pérez-Moreno, S.M., M.J. Gázquez, R. Pérez-López, J.P. Bolivar, 2018. Validation of the BCR sequential extraction procedure for natural radionuclides. Chemosphere, 198: 397-408.

[22] Perin, G., L. Craboledda, M. Lucchesse, R. Cirillo, L. Dotta, M.L. Zanette, A.A. Orio, 1985. Heavy metal speciation in sediments of Northern Adriatic seaNew approach for environmental toxicity determination, in: T. D. Lekkas (Ed.), Heavy metal in the environment, CEP Consultants, Edinburgh.

[23] Affian, K., 2003. Approches environnementales d'un écosystèmelagunaire microtidal (la lagune Ébriéen Côte d'Ivoire), par des études géochimiques et hydrologiques, barthymétriques et hydrologiques: contributions du S.I.G et de la télédétection, UFHB Thesis, Côte d'Ivoire.

[24] Wango, T-E., Y.M. N'guessan, M. Touré, 2016. Tidal waves propagations in the Ébrié lagoon (South west coast of Côte d' Ivoire). IOSR Journal of Applied Physics, 8(6): 89-95.

[25] Pottier, P., K. Affian, M.M.V. Djagoua, K.P. Anoh, Y. Kra, A. Kangah, M. Robin, 2008. La lagune Ébrié à l'épreuve de la pression anthropique, in: Gêolittomer (Eds.),Géographie du littoral de Côte d'Ivoire, éléments de réflexion pour une politique de gestion intégré, La Clonerie, France. 
[26] AFNOR certification X 31-100., 1992. Qualité des sols - Échantillonnage - Méthode de prélèvementd'échantillons de sol. Edition Boutique AFONOR.

[27] AFNOR certification NF EN ISO 16720., 2007. Qualité du sol - Prétraitement des échantillons par lyophilisation pour analysesubséquente. Edition Boutique AFONOR.

[28] AFNOR NF X 31-107., 2003. Qualité du sol - Détermination de la distribution granulométrique des particules du sol - Méthode à la pipette. Edition Boutique AFNOR.

[29] AFNOR NF T 90-112., 1986. Qualité de l'eau - Dosage de huitélémentsmétalliques (Mn, Fe, Co, Ni, Cu, Zn, Ag, Pb) par spectrométried'absorptionatomique dans la flamme. Edition Boutique AFNOR.

[30] Nemati, K., N.K.A. Bakar, M.R. Abas, E. Sobhanzadeh, 2011. Speciation of heavy metals by modified BCR sequential extraction procedure in different depths of sediments from Sungai Buloh, Selangor, Malaysia. Journal of Hazardous Materials, 192: 402-410.

[31] Benson, M.U., F.E. Asuquo, A.B. Williams, J.P. Essien, C.I. Ekong, O. Akpabio, A.A. Olajire, 2016. Source evaluation and trace metal contamination in benthic sediments from equatorial ecosystems using multivariate statistical techniques. PLoS One, 016, 11(6): e0156485.

[32] Saleem, M., J. Iqbal, M.H. Shah, 2015. Geochemical speciation, anthropogenic contamination, risk assessment and source identification of selected metals in freshwater sediments-A case study from Mangla Lake, Pakistan. Environmental Nanotechnology, Monitoring and Management, 4: 27-36.

[33] Bastami, K.D., H. Bagheri, V. Kheirabadi, G.G. Azferani, M.B. Teymori, A. Hamzehpoor, F. Soltani, S. Haghparast, S.R.M. Harami, N.F. Ghorghani, S. Ganj, 2014. Distribution and ecological risk assessment of heavy metals in surface sediments along southeast coast of the Caspian sea. Marine Pollution Bulletin, 81: 262-267.

[34] Hakanson, L., 1980. An ecological risk index for aquatic pollution control, a sedimentological approach. Water research, 14: 975-1001.

[35] Wedepohl, K.H., 1995. The composition of the continental crust. Geochimica et Cosmochimica Acta, 59(7): 1217-1232.

[36] Durand, A., Z. Chase, A.T. Townsend, T. Noble, E. Panietz, K. Goemann,2016. Improved methodology for the microwave digestion of carbonate-rich environmental samples. International Journal of Environmental Analytical Chemistry,96(2):119-136.

[37] Wali, A., G. Collinet, M. Ksibi, 2014. Speciation of heavy metals by modified BCR sequential extraction in soils contaminated by Phosphogypsum in Sfax, Tunisia. Environmental Research, Engineering and Management, 4(70): 14-26.

[38] Xie, Y., G. Lu,C. Yang, L. Qu, M. Chen, C. Guo, Z. Dang, 2018.Mineralogical characteristics of sediments and heavy metal mobilization along a river watershed affected by acid mine drainage. PLos One, 13(1): e0190010.

[39] Baleeiro, A., S. Fiol, S. Otero-Fariña, J. Antelo, 2018. Surface chemistry of iron oxides formed by neutralization of acidic mine waters: Removal of trace metals. Applied Geochemestry, 89: 129-137.

[40] Nworie,O.E., J. Qin, C. Lin, 2017. Differential Effects of Low-Molecular-Weight Organic Acids on the Mobilization of Soil-Borne Arsenic and Trace Metals. Toxics, 5(3): 18 .

[41] Abdu, N., I. Mohammed, 2016. Adsorption-solubility equilibria and speciation of $\mathrm{Pb}, \mathrm{Cd}$, and $\mathrm{Zn}$ in a savanna soil. Spanish Journal of Soil Science, 6(3): 244-260.

[42] Zhao, S., C. Feng, D. Wang, Y. Liu, Z. Shen, 2013. Salinity increases the mobility of Cd, Cu, Mn, and Pb in the sediments of Yangtze Estuary: Relative role of sediments properties and metal speciation. Chemosphere, 91(7):977-984.

[43] Whitby, H., C.M.G.V.D. Berg, 2015. Evidence for copper-binding humic substances in Seawater. Marine Chemestry, 173: 282-290.

[44] Etesami, H., 2018. Bacterial mediated alleviation of heavy metal stress and decreased accumulation of metals in plant tissues: Mechanisms and future prospects. Ecotoxicology and Environment Safety, 147: 175-191.

[45] Paoli, L., A. Vannini, F. Monaci, S. Loppi, 2018. Competition between heavy metal ions for binding sites in lichens: Implications for biomonitoring studies. Chemosphere, 199: 655-666.

[46] Kobielska, P.A., A.J. Howarth, O.K. Farha, S.Nayak, 2018. Metal-organic frameworks for heavy metal removal from water. Coordination of Chemistry Review,358: 92-107.

[47] Oleinikova, O.V., L.S. Shirokova, O.Y. Drozdova, A.S. Lapitskiy, O.S. Pokrovsk, 2018. Low biodegradability of dissolved organic matter and trace metals from subarctic waters. Science of the Total Environment, 618: 174-187.

[48] Neves, V.M., G.M. Heidrich, F.B. Hanzel, E.I. Muller, V.L.Dressle,2018. Rare earth elements profile in a cultivated and non-cultivated soil determined by laser ablation-inductively coupled plasma mass spectrometry. Chemosphere, 198: 409-416.

Ribeiro, I.S., F.A. Genezini, M. Saiki, G.S. Zahn, M. Secco, 2015. Samarium determination by neutron activation analysis in uranium-rich samples. Journal of Radioanalytical and Nuclear Chemistry, 305(1): 299-303. 